一論 文—
（日本化学会誌，1995, (11), p. 881 884)

(C) 1995 The Chemical Society of Japan

\title{
不定比 $\mathrm{Nb}_{5} \mathrm{Sn}_{2} \mathrm{Ga}$ 単結晶の化学組成, 結晶構造, 超伝導転移の関連
}

\author{
(1995 年 7 月 31 日受理)
}

宾戸統悦*·福田承生

\begin{abstract}
溶融 $\mathrm{Sn}$ 自己フラックス法により $\mathrm{Nb}_{5} \mathrm{Sn}_{2} \mathrm{Ga}$ を単結晶の形で得た。この化合物の固溶域は狭く Daltonide 型の三元系化合物と考えられる. 結晶系は正方晶系, 空間群が $\mathrm{D}_{4 \mathrm{~h}}^{18} \mathrm{I} 4 / \mathrm{mcm}$ であり $\mathrm{W}_{5} \mathrm{Si}_{3}$ 型の 規則型三元系化合物である. 化学量論組成に最も近い $\mathrm{Nb}_{5} \mathrm{Sn}_{1.97} \mathrm{Ga}_{1.06}$ では格子定数は $a=1.0586 .(2)$, $c=0.5177(1) \mathrm{nm}, V=0.5802 \times 10^{-27} \mathrm{~m}^{3}$ である. 超伝導転移の中点温度 $\left(T_{\mathrm{c}}\right.$ mid. $)$ は $\mathrm{Ga}$ の多いものか ら少ないものに向かって順に低い値へ変わった. つをり $\mathrm{Nb}_{5} \mathrm{Sn}_{1.95} \mathrm{Ga}_{1.08}, \mathrm{Nb}_{5} \mathrm{Sn}_{1.97} \mathrm{Ga}_{1.06}, \mathrm{Nb}_{5} \mathrm{Sn}_{2.12}$ $\mathrm{Ga}_{0.94}$ に対して $2.13,1.75,1.69 \mathrm{~K}$ となった。前者ほど, 単位格子容積が小さく, $\mathrm{Nb}-\mathrm{Nb}$ 間の距離が近 い.
\end{abstract}

\section{1 緒 言}

周期表の 5 族元素 $(\mathrm{V}, \mathrm{Nb}, \mathrm{Ta})$ と13 族元素 $(\mathrm{Al}, \mathrm{Ga}$ など) ま たは14 族元素 $(\mathrm{Si}, \mathrm{Ge}, \mathrm{Sn}$ など）との間に原子比 $3: 1$ で形成さ れる A15 型二元系化合物 (立方晶系, 空間群 : Pm3n) は, 優れ た超厷導物性を示すことで知られている1),2). 従って, A15 型の 結晶構造を維持しつつ, 構成元素の一部を他の元素で置換する研 究が, 例えば電子状態密度と超伝導転移温度との関係への興味な どから数多くなされてきた ${ }^{3)}$. しかし 5 族一13族，5族一14族か ら構成される三元系の全く新しい化合物を合成する研究はこれま でほとんどない，著者らは溶融金属フラックス法を用い種々の新 三元系化合物を合成する研究を行ってきた，例えば溶融した Sn を自己フラックスとする方法で現在までに $\mathrm{Nb}_{5} \mathrm{Sn}_{2} \mathrm{Ga}^{4)-6)}, \mathrm{Ta}_{5} \mathrm{Sn}$ $\mathrm{Ga}_{2}{ }^{7), 8)}, \mathrm{V}_{2} \mathrm{Sn}_{2} \mathrm{Ga}^{9), 10)}, \mathrm{Nb}_{5}\left(\mathrm{Ge}_{x}, \mathrm{Sn}_{1-x}\right)_{2} \mathrm{Ge}^{11)-13)}$ といった新化合 物を単結晶の形で合成し報告してきた. 先頭と二番目の化合物に ついては超伝導転移が認められた．ここではとくに $\mathrm{Nb}_{5} \mathrm{Sn}_{2} \mathrm{Ga}$ の 化学組成の微小な変化が結晶構造上における原子間距離および超 伝導転移にどのように影響するかを中心に調べた結果を述べる。

\section{2 実験方法}

\section{1 単結晶合成}

原料として $99.9 \% \mathrm{Nb}, 99.999 \% \mathrm{Ga}, 99.999 \% \mathrm{Sn}$ を用いた. $\mathrm{Nb}$ と Ga を原子比で 2: 1, 3:1,4:1にとり，これに Sn を加えた. $(\mathrm{Nb}+\mathrm{Ga})$ と $\mathrm{Sn}$ の重量比を $1: 5$, つまり $\mathrm{Sn}$ 大過剩の出発組成 にした.これらを混合後, 高純度アルミナ(SSA-S) 製のタンマ ン管に入れ，嵞型抵抗炬(発熱体：SiC) 中に配置した. 高純度 ヘリウムを $200 \mathrm{ml} \cdot \mathrm{min}^{-1}$ の流量で流しなが $5400^{\circ} \mathrm{C} \cdot \mathrm{h}^{-1}$ の速 度で $1400{ }^{\circ} \mathrm{C}$ ま昇温, 同温度で 10 時間保持後, $1^{\circ} \mathrm{C} \cdot \mathrm{h}^{-1}$ の速 度で $1000{ }^{\circ} \mathrm{C}$ をで徐冷した.この後, 炬の電源を切り室温まで放

東北大学金属材料研究所, 980-77 仙台市青葉区片平丁 2-1-1
冷した．タンマン管を取り出して割り、インゴットを $6 \mathrm{M} \mathrm{HCl}$ に浸漬してSnを溶かし，単結晶を分離した．最後に純水を用い て単結晶を洗浄した．表 1 に単結晶合成の概要を示す.

\section{2 解 析}

得られた単結晶の外形を走査型電子顕微鏡 (SEM) で観察し た. 化学組成の分析は, 単結晶を粉碎し, これにフッ化水素酸と 硝酸の混酸を加え，約 $70^{\circ} \mathrm{C}$ 加熱して溶玑した溶液に対し誘導 結合プラズマ発光分析(ICP-AES) を適用し行った. 単結晶の晶 系および空間群はプリセッション写真法により決定し, 精密な格 子定数および原子位置は四軸型単結晶回折計のデータにもとつい て決定した. また単結晶の成長面, 伸長方位をラウエ写真法で調 べた．交流磁化率の測定により超伝導転移を調べた．さらに，一 部の試料については直流四端子法で電気抵抗の温度依存性を調へ た。

Table 1 Preparation of the $\mathrm{Nb}_{5} \mathrm{Sn}_{2}$ Ga single crystals by the flux method using molten $\mathrm{Sn}$ as a self flux

$$
\text { raw materials; } \mathrm{Nb}, \mathrm{Ga} \text { and } \mathrm{Sn}
$$

melt in an alumina crucible under He stream

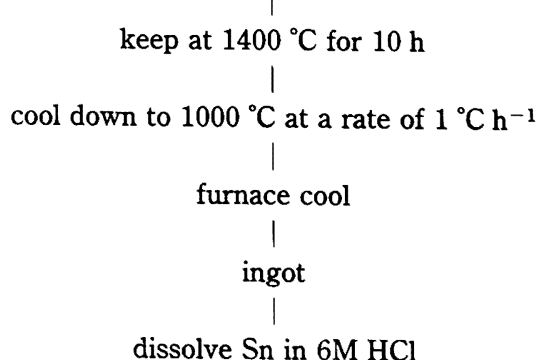

single crystals of $\mathrm{Nb}_{5} \mathrm{Sn}_{2} \mathrm{Ga}$ 


\section{3 結果および考察}

\section{1 単結晶の外観および化学組成}

単結晶の外観(SEM 像) を図 1 に示す。銀色の直方体であり， 長いもので約 $10 \mathrm{~mm}$ に達する. $\mathrm{Nb}, \mathrm{Sn}$ そして $\mathrm{Ga}$ からなる三元 系の化合物である. Sn $\left(\mathrm{mp} 232^{\circ} \mathrm{C}, \mathrm{bp} 2275^{\circ} \mathrm{C}\right)$ は溶融金属フラ ックス法における有用なフラックス剂として以前より注目されて きた ${ }^{14)}$. 本実験の結果によれば Sn はフラックス剤として作用し たのみでなく，化合物形成に参加しているので自己フラックス剂 として機能したと捉えられる，出発時の Nb と Ga の割合を变化 させると得られる単結晶の化学組成も変化した。この結果を表2 に示す. 出発時の $\mathrm{Nb}$ と $\mathrm{Ga}$ の原子比 $2: 1,3: 1,4: 1$ に対応 し, 得られる単結晶の化学組成は $\mathrm{Nb}_{5} \mathrm{Sn}_{1.95} \mathrm{Ga}_{1.08}, \mathrm{Nb}_{5} \mathrm{Sn}_{1.97}$ $\mathrm{Ga}_{1.06}$ および $\mathrm{Nb}_{5} \mathrm{Sn}_{2.12} \mathrm{Ga}_{0.94}$ となった。出発組成中に占める $\mathrm{Ga}$ の割合が多い場合には，得られる化合物中に占める $\mathrm{Ga}$ の割合も 多い. しかし, 出発組成を大幅に変えてむ, 得られる単結晶の化 学組成は上述したようにわずかに変化するだけであり，いずれす 化学量論組成 $\mathrm{Nb}_{5} \mathrm{Sn}_{2} \mathrm{Ga}$ に収斂した。従って，この化合物は構成 元素同士が広い固溶域をむたない Daltonide 型の三元系化合物と 考えられる. 三者の中にあっては $\mathrm{Nb}_{5} \mathrm{Sn}_{1.97} \mathrm{Ga}_{1.06}$ が化学量論組 成に最む近い，この化合物のアーク溶融法による合成を試みたが 成功しなかった：このため，現状ではこの化合物は分解溶融型で あると考えている，図 2 に Nb-Sn-Ga の三元系図を示す，NbGa 系には少なくとむ 8 件の異なる状態図が報告されていて，化 合物の数は図 2 に記したように8 個に達するが不確実な部分が 多い。例えばJorda ${ }^{15)}$ の状態図では化合物は $\mathrm{Nb}_{4} \mathrm{Ga}_{5}, \mathrm{Nb}_{5} \mathrm{Ga}_{4}$ ， $\mathrm{Nb}_{5} \mathrm{Ga}_{3} ， \mathrm{Nb}_{3} \mathrm{Ga}$ の 4 個たけとされる. Nb-Sn 系には 3 個の化合

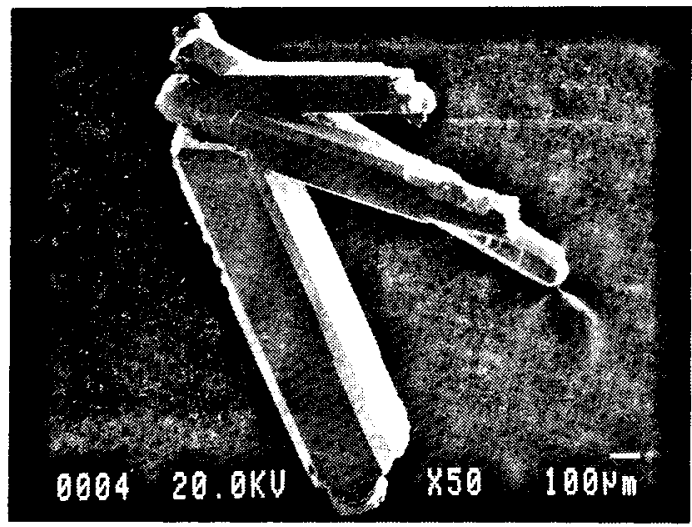

Fig. 1 SEM photograph of the $\mathrm{Nb}_{5} \mathrm{Sn}_{1.95} \mathrm{Ga}_{1.08}$. White bar represents $100 \mu \mathrm{m}$.

Table 2 Relationship between the nominal composition and the chemical formula of the obtained crystals.

\begin{tabular}{cc}
$\begin{array}{c}\text { Nominal composition } \\
\mathrm{Nb}: \mathrm{Ga} \text { (atomic ratio) }\end{array}$ & $\begin{array}{c}\text { chemical formula of } \\
\text { obtained crystals }\end{array}$ \\
\hline $2: 1$ & $\mathrm{Nb}_{5} \mathrm{Sn}_{1.95} \mathrm{Ga}_{1.08}$ \\
$3: 1$ & $\mathrm{Nb}_{5} \mathrm{Sn}_{1.97} \mathrm{Ga}_{1.06}$ \\
$4: 1$ & $\mathrm{Nb}_{5} \mathrm{Sn}_{2.12} \mathrm{Ga}_{0.94}$
\end{tabular}

a) Sn was added to this mixture in the ratio $5: 1$ by weight.

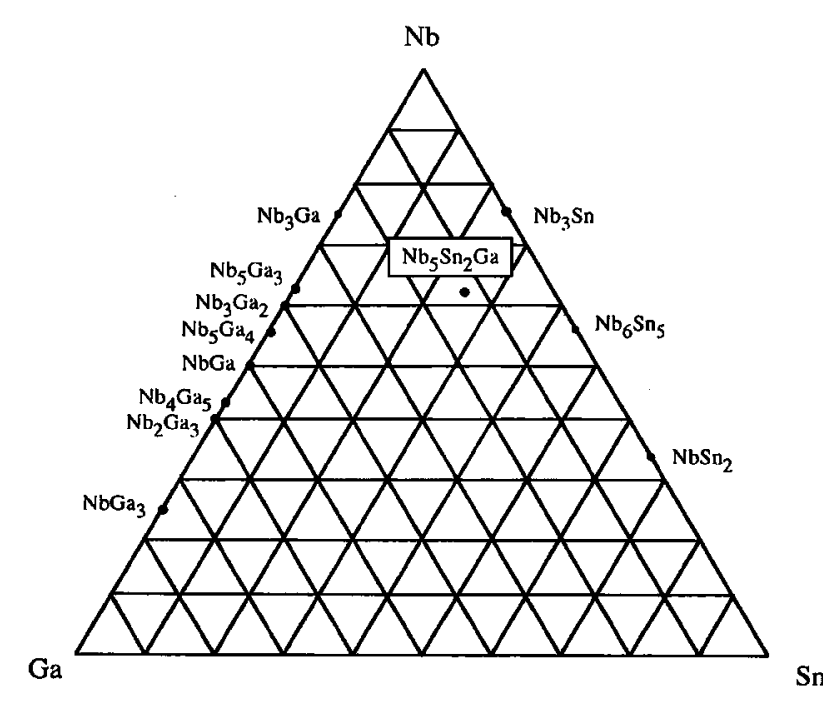

Fig. 2 Ternary phase diagram in the system of $\mathrm{Nb}, \mathrm{Sn}$ and Ga. The position of the $\mathrm{Nb}_{5} \mathrm{Sn}_{2} \mathrm{Ga}$ is shown in the figure.

物が存在する、Ga-Sn 系には化合物が存在しない，同三元系図 上に $\mathrm{Nb}_{5} \mathrm{Sn}_{2} \mathrm{Ga}$ の位㯰を示した。この系には他の三元系化合物は 全く報告されておらず，現状では本化合物のみが存在する.

\section{2 単結晶の結晶構造および化学組成による原子間距離の变} 化

この化合物は正方晶系 $\mathrm{W}_{5} \mathrm{Si}_{3}$ 型(空間群 : $\left.\mathrm{I} 4 / \mathrm{mcm}\right)^{16}$ ) に属し， その規則三元型の化合物と捉えられる. 先に，示した図 1 の単 結晶の発達面は(100)，(110）およびそれらに等価な面であり， 伸長方向は[001]である．定比組成に最む近い $\mathrm{Nb}_{5} \mathrm{Sn}_{1.97} \mathrm{Ga}_{1.06}$ のX 線密度は8.816 $\mathrm{g} \cdot \mathrm{cm}^{-3}$ である.この単結晶に対し $\mathrm{H}_{2} \mathrm{O}$ を 使用し，ピクノメーター法により密度を実測したところ8.80 g. $\mathrm{cm}^{-3}$ であった．得られた化合物 $\mathrm{Nb}_{5} \mathrm{Sn}_{1.95} \mathrm{Ga}_{1.08}, \mathrm{Nb}_{5} \mathrm{Sn}_{1.97} \mathrm{Ga}_{1.06}$ および $\mathrm{Nb}_{5} \mathrm{Sn}_{2.12} \mathrm{Ga}_{0.94}$ の格子定数は順に $a=1.0584(1)$, $c=0.5175(1) \mathrm{nm} ; a=1.0586(2), c=0.5177(1) \mathrm{nm} ; a=1.0606(2)$, $c=0.5196(1) \mathrm{nm}$ であった. Ga の多い化合物ほど格子定数およ び単位格子容積が小さくなっている．表 3 に各化合物の格子定 数および原子間距離の詳細を示す.さらに化合物の理想的な原子 配列(正方晶の $\mathrm{c}$ 軸方向への投影) を図 3 に示す，大円は $\mathrm{Sn}$ ，中 円は $\mathrm{Nb}$ ，小円は $\mathrm{Ga}$ である、また，白円が $Z=0$, 点つき円が $Z=1 / 4,3 / 4$ ，黒円が $Z=1 / 2$ の座標を示す．この化合物は $\mathrm{W}_{5} \mathrm{Si}_{3}$

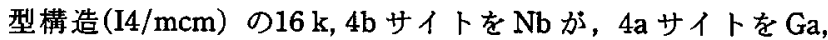
$8 \mathrm{~h}$ サイトを Sn が占める形をとる. Daltonide 型の三元系化合物 と考えると基本的には $\mathrm{Ga}$ と $\mathrm{Sn}$ の相互置換の許容範囲は狭いと みられる。いま， $\mathrm{Ga}$ が最も少なく $\mathrm{Sn}$ の最む多い化合物 $\mathrm{Nb}_{5}$ $\mathrm{Sn}_{2.12} \mathrm{Ga}_{0.94}$ K注目すると表 3 からわかるように $\mathrm{Ga}$ 原子の周りの

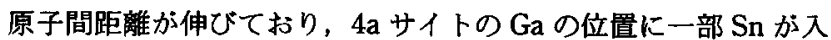
っていると考えられる. $\mathrm{Ga}$ と $\mathrm{Sn}$ の金属半径(配位数：12) はそ れぞれ0.153, $0.158 \mathrm{~nm}$ であり，その差がこの結果に反映されて 単位胞む大きくなったと考えられる. Ga が最も多い化合物 $\mathrm{Nb}_{5}$ $\mathrm{Sn}_{1.95} \mathrm{Ga}_{1.08}$ では逆に $8 \mathrm{~h}$ サイトの $\mathrm{Sn}$ 位㯰に一部 $\mathrm{Ga}$ がはいって いると考えられる。化学量論組成に最む近い $\mathrm{Nb}_{5} \mathrm{Sn}_{1.97} \mathrm{Ga}_{1.06}$ で は Ga と Sn はほとんどそれそれの定まったサイトのみに存在す 
Table 3 Lattice parameters and interatomic distances of $\mathrm{Nb}_{5} \mathrm{Sn}_{2} \mathrm{Ga}$; space group, tetragonal, $I 4 / m \mathrm{~cm}, Z=4$, ordered $\mathrm{W}_{5} \mathrm{Si}_{3}$-type structure.

\begin{tabular}{llll} 
& $\begin{array}{l}\mathrm{Nb}_{5} \mathrm{Sn}_{1.95} \\
\mathrm{Ga}_{1.08}\end{array}$ & $\begin{array}{l}\mathrm{Nb}_{5} \mathrm{Sn}_{1.97} \\
\mathrm{Ga}_{1.06}\end{array}$ & $\begin{array}{l}\mathrm{Nb}_{5} \mathrm{Sn}_{2.12} \\
\mathrm{Ga}_{0.94}\end{array}$ \\
\hline$a / \mathrm{nm}$ & $1.0584(1)$ & $1.0586(2)$ & $1.0606(2)$ \\
$c / \mathrm{nm}$ & 0.5175 & $0.5177(1)$ & $0.5196(1)$ \\
$V / 10^{-27} \mathrm{~m}^{3}$ & 0.5797 & 0.5802 & 0.5845 \\
$\mathrm{Nb}(1)-\mathrm{Nb}\left(1^{\mathrm{ii}}\right)$ & $0.3098(2)$ & $0.3102(3)$ & $0.3085(2)$ \\
$\mathrm{Nb}\left(1^{\mathrm{i}}\right)-\mathrm{Nb}\left(1^{\mathrm{ii}}\right)$ & $0.3404(1)$ & $0.3407(2)$ & $0.3426(1)$ \\
$\mathrm{Nb}\left(1^{\mathrm{i}}\right)-\mathrm{Nb}\left(1^{\mathrm{iii}}\right)$ & $0.3473(2)$ & $0.3473(3)$ & $0.3498(2)$ \\
$\mathrm{Nb}\left(1^{\mathrm{ii}}\right)-\mathrm{Nb}\left(1^{\mathrm{iii}}\right)$ & $0.3010(1)$ & $0.3008(2)$ & $0.3021(1)$ \\
$\mathrm{Nb}(1)-\mathrm{Nb}(2)$ & $0.3320(1)$ & $0.3320(2)$ & $0.3317(1)$ \\
$\mathrm{Nb}\left(1^{\mathrm{ii}}\right)-\mathrm{Sn}$ & $0.281(1)$ & $0.281(1)$ & $0.281(1)$ \\
$\mathrm{Nb}\left(1^{\mathrm{iii}}\right)-\mathrm{Sn}$ & $0.3018(6)$ & $0.3020(6)$ & $0.3024(6)$ \\
$\mathrm{Nb}\left(1^{\mathrm{iv}}\right)-\mathrm{Sn}$ & $0.280(1)$ & $0.280(1)$ & $0.281(1)$ \\
$\mathrm{Nb}(1)-\mathrm{Ga}$ & $0.2776(1)$ & $0.2776(2)$ & $0.2794(1)$ \\
$\mathrm{Nb}(2)-\mathrm{Nb}\left(2^{\mathrm{v}}\right)$ & $0.2588(1)$ & $0.2589(1)$ & $0.2598(1)$ \\
$\mathrm{Nb}(2)-\mathrm{Sn}$ & $0.2828(9)$ & $0.2829(9)$ & $0.2835(9)$ \\
$\mathrm{Sn}-\mathrm{Sn}$ & $0.357(1)$ & $0.357(1)$ & $0.358(1)$ \\
$\mathrm{Ga}-\mathrm{Ga}^{\mathrm{v}}$ & $0.2588(1)$ & $0.2589(1)$ & $0.2598(1)$ \\
$\mathrm{Symm}$ & $1 / 2-x, 1 / 2-y$ & $1 / 2-2(\mathrm{ii}) 1 / 2$
\end{tabular}

Symmetry code: (i) $1 / 2-x, 1 / 2-y, 1 / 2-z$; (ii) $1 / 2-y, 1 / 2-x, z$; (iii) $1 / 2-y, 1 / 2+x, 1 / 2+z$;

(iv) $1 / 2-x, 1 / 2+y, z$; (v) $x, y, 1-z$;

(vi) $x, 1-y, 1 / 2+z$; (vii) $1-y, 1-x, 1 / 2+z$.

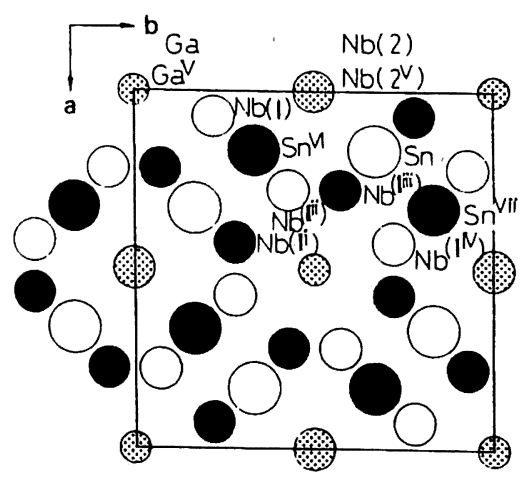

Fig. 3 Arrangement of atoms in the $\mathrm{Nb}_{5} \mathrm{Sn}_{2} \mathrm{Ga}$ crystal projected along the c-axis, where the large circles are $\mathrm{Sn}$, the medium circles are $\mathrm{Nb}$, and the small circles are $\mathrm{Ga}$. The open circles are located at $Z=0$, the dotted circles at $Z=1 / 4,3 / 4$, and the solid circles at $Z=1 / 2$. The symmetry code is the same as shown in Table 3.

\section{ると考えられる.}

\section{3 単結晶の超伝導転移およびその化学組成と結晶構造との} 関連

金属間化合物において, 超伝導の有無, 超伝導転移温度の高低 を議論する場合には結晶構造, 非化学量論性, 格子秩序度, 一部 には超伝導転移と温度的に近接して起こる相変態の影響などが重 要な検討項目となる．このことに加え一原子当たりの価電子数 $\left(V_{\mathrm{E}} / A\right)$ と超伝導転移温度 $T_{\mathrm{c}}$ の関係が Matthias 則とよばれる 経験則として知られていて化合物探索に一つの指針を与えてき た ${ }^{17)} . V_{\mathrm{E}} / A$ と $T_{\mathrm{c}}$ の相関をみると二つの鋭いピークが $V_{\mathrm{E}} / A$ $=4.5 \sim 4.7$, および $6.3 \sim 6.5$ んられる. 冒頭述べた $\mathrm{A} 15$ 型化
合物はその特改的な結晶構造 (とくに 5 族元素で構成される直鎖 およびそれらが直交して存在している特徴ある形態）とともに, $V_{\mathrm{E}} / A$ が 4.5 4.7の範囲にあり最も超伝導転移温度の高いグルー プに属することにおいて知られる. $\mathrm{Nb}_{5} \mathrm{Sn}_{2} \mathrm{Ga}$ について $V_{\mathrm{E}} / A$ を 算出してみた結果 4.4 となった. 事実, $\mathrm{Nb}_{5} \mathrm{Sn}_{2} \mathrm{Ga}$ は超伝導を示

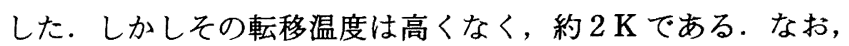
粉末に粉砕して $T_{\mathrm{c}}$ 測定しても類似の転移特性を示すので $\mathrm{Nb}_{5}$ $\mathrm{Sn}_{2} \mathrm{Ga}$ が超伝導となることは間違いない。超伝導転移の様子を 調べ化学組成, 結晶構造と対比させた. 図 4 および表 4 にその 結果を示す. $\mathrm{Ga}$ が最も多く $\mathrm{Sn}$ の最も少ない化合物 $\mathrm{Nb}_{5} \mathrm{Sn}_{1.95}$ $\mathrm{Ga}_{1.08}$ の超伝導転移開始温度 $\left(T_{\mathrm{c}}\right.$ on.) および超伝導転移の中点 温度 $\left(T_{\mathrm{c}}\right.$ mid. $)$ は2.40, $2.13 \mathrm{~K}$ であり三者の中では最も高い温度 を示す．しかし超伝導転移の幅は大変広い，先に述べたように $\mathrm{Ga}$ サイトに一部 Sn が入ったことによる影響とみられる．化学 量論組成に最も近い $\mathrm{Nb}_{5} \mathrm{Sn}_{1.97} \mathrm{Ga}_{1.06}$ では $\mathrm{Ga}$ と $\mathrm{Sn}$ の相互置換を 考虑に入れる必要が最も少なく, 事実, 超伝導転移は最も鋭敏に 起こった．超伝導転移の中点温度 $\left(T_{\mathrm{c}}\right.$ mid.) に注目すると $\mathrm{Ga}$ の 多いものから順に $2.13,1.75,1.69 \mathrm{~K}$ となった．前者ほと，単位 格子容積が小さく, 超伝導に最も関連するとみられる $\mathrm{Nb}-\mathrm{Nb}$ 間 の距離(表 3) は近い.

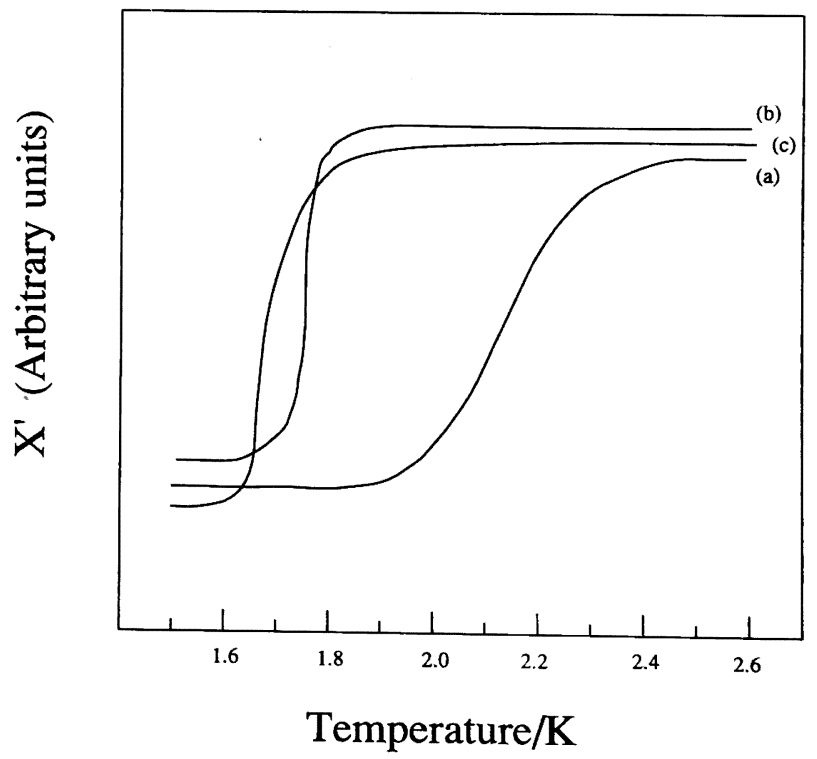

Fig. 4 Relationship between the chemical composition and temperature dependence of the $\mathrm{AC}$ magnetic susceptibility for $\mathrm{Nb}_{5} \mathrm{Sn}_{1.95} \mathrm{Ga}_{1.08}(\mathrm{a}), \mathrm{Nb}_{5} \mathrm{Sn}_{1.97} \mathrm{Ga}_{1.06}(\mathrm{~b})$ and $\mathrm{Nb}_{5} \mathrm{Sn}_{2.12} \mathrm{Ga}_{0.94}$ (c).

Table 4 Relationship between the chemical composition and the superconductivity of $\mathrm{Nb}_{5} \mathrm{Sn}_{2} \mathrm{Ga}$.

\begin{tabular}{|c|c|c|c|}
\hline & $\begin{array}{l}\mathrm{Nb}_{5} \mathrm{Sn}_{1.95} \\
\mathrm{Ga}_{1.08}\end{array}$ & $\begin{array}{l}\mathrm{Nb}_{5} \mathrm{Sn}_{1.97} \\
\mathrm{Ga}_{1.06}\end{array}$ & $\begin{array}{l}\mathrm{Nb}_{5} \mathrm{Sn}_{2.12} \\
\mathrm{Ga}_{0.94}\end{array}$ \\
\hline$T_{\mathrm{c}}$ onset $/ \mathrm{K}$ & 2.40 & 1.82 & 1.90 \\
\hline$T_{\mathrm{c}}$ midpoint $/ \mathrm{K}^{a)}$ & 2.13 & 1.75 & 1.69 \\
\hline
\end{tabular}

a) $T_{\mathrm{c}}$ midpoint was defined at the midpoint in the transition curve with a $10 \%-90 \%$ cutoff criterion. 
Table 5 Electric properties of $\mathrm{Nb}_{5} \mathrm{Sn}_{1.97} \mathrm{Ga}_{1.06}$

$\begin{array}{ll}\rho(298 \mathrm{~K}) & 120 \mu \Omega \mathrm{cm} \\ \rho(4.2 \mathrm{~K}) & 10 \mu \Omega \mathrm{cm} \\ \text { resistivity ratio, RR } & \rho(298 \mathrm{~K}) / \rho(4.2 \mathrm{~K})=12\end{array}$

\section{4 電気的性質}

$\mathrm{Nb}_{5} \mathrm{Sn}_{1.97} \mathrm{Ga}_{1.06}$ の試料を用いて $298,4.2 \mathrm{~K}$ での電気抵抗を調べ たところ，それぞれ $120,10 \mu \Omega \mathrm{cm}$ となり，その比つまり残留抵 抗比は12となった．結果を表 5 に示す.

\section{4 ま とめ}

容融 $\mathrm{Sn}$ 自己フラックス法により $\mathrm{Nb}_{5} \mathrm{Sn}_{2} \mathrm{Ga}$ を単結晶の形で得 た. 出発組成中に占める $\mathrm{Ga}$ の割合が多い場合には, 得られる化 合物中に占める $\mathrm{Ga}$ の割合も多い。出発組成を大幅に変えても, 得られる単結晶の化学組成はわずかに変化するたけであり, 化学 量論組成 $\mathrm{Nb}_{5} \mathrm{Sn}_{2} \mathrm{Ga}$ に収斂する. 従って, 本化合物は構成元素同 士の固溶域の狭い Daltonide 型の三元系化合物と考えられる. 結 晶系は正方晶系, 空間群が $\mathrm{D}_{4 \mathrm{~h}}^{18} \mathrm{I} / 4 / \mathrm{mcm}$ であり $\mathrm{W}_{5} \mathrm{Si}_{3}$ 型の規則 型三元系化合物と捉えられる．単結晶の発達面は (100), (110) およびそれらに等価な面であり, 伸長方向は[001]である. 定 比組成に最む近い $\mathrm{Nb}_{5} \mathrm{Sn}_{1.97} \mathrm{Ga}_{1.06}$ のX線密度は8.816 $\mathrm{g} \cdot \mathrm{cm}^{-3}$ で あり，この化合物に対しピクノメーター法により密度を実測した ところ $8.80 \mathrm{~g} \cdot \mathrm{cm}^{-3}$ であった. $\mathrm{Nb}_{5} \mathrm{Sn}_{2} \mathrm{Ga}$ についての $V_{\mathrm{E}} / A$ の算 出結果は4.4であり，この化合物は超伝導を示す．超伝導転移の 中点温度 $\left(T_{\mathrm{c}}\right.$ mid.) は $\mathrm{Ga}$ の多いものから少ないものに向かって 順に低い値へ変わった．つまり $\mathrm{Nb}_{5} \mathrm{Sn}_{1.95} \mathrm{Ga}_{1.08}, \mathrm{Nb}_{5} \mathrm{Sn}_{1.97} \mathrm{Ga}_{1.06}$, $\mathrm{Nb}_{5} \mathrm{Sn}_{2.12} \mathrm{Ga}_{0.94}$ に対して2.13, 1.75, $1.69 \mathrm{~K}$ となった. 前者ほど, 単位格子容積が小さく, 超伝導に最む関連するとみられる $\mathrm{Nb}-$ $\mathrm{Nb}$ 間の距離は前者ほどより近づく. $\mathrm{Nb}_{5} \mathrm{Sn}_{1.97} \mathrm{Ga}_{1.06}$ の298, 4.2 $\mathrm{K}$ での電気抵抗值はそれそれ $120,10 \mu \Omega \mathrm{cm}$ であり, 残留抵抗比 (RR) は12である.

本研究は東北大学金属材料研究所強磁場超卮導センターの超卮 導研究費の援助を受けて実施した. 東北大学金属材料研究所の高
田九二雄博士に笡密な化学分析で, 野手竜之介氏に化合物合成 で，村上義弘氏に SEM 観察でご協力をいたたいた．本研究をま とめるにあたっては東京大学理学系研究科の堀内弘之助教授, 東 北大学金属材料研究所の請井一利助教授および佐々木孝彦博士, 大阪府立大学先端科学研究所の豊田直樹教授, 科学技術庁金属材 料技術研究所の葉 金花主任研究員, 文部省高エネルギー物理学 研究所の田中雅彦博士, 神奈川大学, 岡田 繁教授, 工藤邦男教 授にご教示とご協力を賜わりました．心より感謝を申し上げま す.

1) J. P. Charlesworth, I. Macphail, P. E. Madsen, J. Material Sci., 5, 580(1970).

2) J. Muller, Rep. Prog. Phys., 43, 641(1980).

3) S. E. Rasmussen, R. G. Hazell, Acta Chemica Scandinavi$c a, \mathrm{~A} 32,785$ (1978).

4) T. Shishido, K. Ukei, N. Toyota, T. Sasaki, Y. Watanabe, K. Motai, H. Takeya, H. Takei, T. Fukuda, J. Crystal Growth, 96, 1(1989).

5) K. Ukei, T. Shishido, T. Fukuda, Acta Crystallogr., C45, 349(1989).

6) T. Shishido, K. Ukei, N. Toyota, M. Tanaka, H. Horiuchi, T. Fukuda, J. Alloys and Compounds, 202, L1 (1993).

7) T. Shishido, J. Ye, N. Toyota, K. Ukei, T. Sasaki, H. Horiuchi, T. Fukuda, Jpn. J. Appl. Phys., 28, 1519(1989).

8) J. Ye, H. Horiuchi, T. Shishido, K. Ukei, T. Fukuda, Acta. Cryst., C46, 1193(1990).

9) J. Ye, H. Horiuchi, T. Shishido, T. Fukuda, Acta Cryst., C46, 1195(1990).

10) J. Ye, H. Horiuchi, T. Shishido, N. Toyota, K. Ukei, T. Sasaki, T. Fukuda, J. Crystal Growth, 99, 969(1990).

11) T. Shishido, M. Tanaka, H. Horiuchi, N. Toyota, T. Fukuda, J. Alloys Compounds, 178, L5(1992) .

12) M. Tanaka, H. Horiuchi, T. Shishido, T. Fukuda, Acta Cryst., C49, 437(1993).

13）宍戸統悦, 田中雅彦, 堀内弘之, 豊田直樹, 福田承生, 日化, 1994, 262.

14）岡田 繁, 阿刀田徹三, 神奈川大学工学研究所所報第 4 号, 56(1981).

15) J. L. Jorda, R. Flukiger, J. Muller, J. Less-Common Metals, 55, 249(1977).

16) B. Aronsson, Acta Chem. Scand., 9, 1107(1955).

17）豊田直樹, 機能材料, No. 1, 34(1986).

\title{
Influence of Chemical Composition on Crystal Structure and Superconducting Transition in Non-stoichiometric $\mathrm{Nb}_{5} \mathrm{Sn}_{2} \mathrm{Ga}$ Single Crystals
}

\author{
Toetsu SHISHIDO* and Tsuguo FUKUDA \\ Institute for Materials Research (IMR), Tohoku University; \\ 2-1-1 Katahira-cho, Aoba-ku, Sendai-shi 980 Japan
}

Single crystals of a new ternary intermetallic compound $\mathrm{Nb}_{5} \mathrm{Sn}_{2} \mathrm{Ga}$ have been synthesized by a self flux method using molten tin as a solvent. Solid solution range of the compound is very narrow. This compound is probably a Daltonide-type ternary intermetallic compound. The crystal structure shows a tetragonal symmetry, space group $\mathrm{D}_{4 \mathrm{~h}}^{18} \mathrm{I} 4 / \mathrm{mcm}$, ordered $\mathrm{W}_{5} \mathrm{Si}_{3}$-type structure. Lattice parameters of the single crystals of $\mathrm{Nb}_{5} \mathrm{Sn}_{1.97} \mathrm{Ga}_{1.06}$, which composition is the nearest to the stoichiometric composition, are $a=1.0586(2), c=0.5177$ (1) nm and $V=0.5802 \times 10^{-27} \mathrm{~m}^{3}$. The unit cell volumes decrease with increasing gallium content in the chemical formula. As a result, intermetallic distances $\mathrm{Nb}$ to $\mathrm{Nb}$ also decrease. The values of the $T_{\mathrm{c}}$ (midpoint) increase with increasing gallium content in the chemical formula: $1.69,1.75$ and 2.13 for $\mathrm{Nb}_{5} \mathrm{Sn}_{2.12} \mathrm{Ga}_{0.94}, \mathrm{Nb}_{5} \mathrm{Sn}_{1.97} \mathrm{Ga}_{1.06}$ and $\mathrm{Nb}_{5} \mathrm{Sn}_{1.95} \mathrm{Ga}_{1.08}$, respectively. 